\title{
The Impact of Accounting on Environmental Costs to Improve the Quality of Accounting Information in the Jordanian Industrial Companies
}

\author{
Atala M. Alqtish ${ }^{1} \&$ Adel M. Qatawneh ${ }^{1}$ \\ ${ }^{1}$ Accounting Department, Faculty of Economics \& Administrative Sciences, Al-Zaytoonah University of Jordan, \\ Jordan \\ Correspondence: Atala M. Alqtish, Accounting Department, Faculty of Economics \& Administrative Sciences, \\ Al-Zaytoonah University of Jordan. E-mail: Atalla.Q@zuj.edu.jo
}

Received: April 19, 2017

Accepted: May 12, 2017

Online Published: May 17, 2017

doi:10.5539/ijbm.v12n6p104

URL: https://doi.org/10.5539/ijbm.v12n6p104

\begin{abstract}
The Impact of Accounting of Environmental Costs to Improve the Quality of Accounting Information in the Jordanian Industrial Companies is a study aimed to explore the importance of accounting on environmental cost in the improve of the quality of accounting information. Data were collected through from the Jordanian companies and a questionnaire distributed among the workers of offices and departments of accounting in the industrial companies listed in Jordan stock market. The study came up with the following findings: The study has shown that there exists a significant statistical relationship between the size of environmentally-related accounting disclosure of information for publicly owned companies and the adequacy of financial listing of such companies. The study has shown that there exists a significant statistical relationship between Investors decisions and the information provided by the collective performance disclosure. As per the study results, we recommend the following: The necessity of accountants' obligation towards environmentally-related auditing information provided with the financial reports, and the necessity of emphasizing on information importance as provided by the environmentally-related collective performance.
\end{abstract}

Keywords: accounting, Jordanian industrial companies

\section{Introduction}

Interest in the environment is one of the most important issues that developing countries care for, where a good portion of the budgets of these governments is devoted to protect the environment. Interest in the environment in these countries appears in the form of protecting the environment of the latest dangerous effects resulted from contaminants and smoke emitted from cars and plant chimneys which caused environmental instability in the world (Fayoumi, 1998: 12). Hence, the society in which these plants and companies work should economically contribute to improve the level of cleanliness in air and soil. People who are interested in studying the concept, aims and the controllers of estimating the disclosure of social responsibility for economic unity see that, by the end of eighties, the focus on social and environmental issues changed from disclosure of information about working force and added value into the necessity of disclosing environmental information, whether it is through the annual financial reports or other means of disclosure (Fayoumi, 1998: 13). Therefore, it can be said that if accounting succeeds in revealing the efficiency of economic unit in its social responsibilities, especially in the control of environmental pollution, as it did before in revealing suitable and enough information about the efficiency of economic or financial performance, it will certainly play an important role to change the behavior of decision-makers and people who are interested in the economic unity and increasing their profits when they take the right decision (Fayoumi, 1998: 14). This study attempts to analyze the impact of accounting for environmental costs to improve the quality of accounting information in the Jordanian industrial companies.

\section{Importance of the Study}

The importance of this study stems from the importance of environment in the different aspects of human beings. One of these aspects is the interest of governments and societies in the environment where plants and companies cause pollution and destruction to the environment, and they constantly call to protect the environment and reach a good quality of cleanliness in air, water and all other natural resources. Cleanliness of water, air and soil will 
be reflected on the human being. Therefore, it is important to issue laws and regulations to protect the environment and society in accordance with the necessity of every society and the circumstances resulted from the pollution and destruction of these societies. In such situations, it is very important to maintain credibility in the information disclosed by economic institutions about society and the environment. For the reasons mentioned above, environmental, social accounting disclosure has gained the attention of many studies, especially field studies, to determine its aims, importance and limitations as a vital requirement for people interested in unity, especially investors and individuals. To this end, this study aims to clarify the importance environmental, social accounting disclosure by industrial companies registered in Amman financial market in the Hashemite Kingdom of Jordan in order to improve the quality of accounting information and increase objectivity and trust.

\section{Aims and Objectives}

This study aims to investigate the impact of environmental accounting on the improvement of the quality of accounting information in industrial companies through: Defining environmental accounting and the quality of accounting information, and showing the importance of information provided by social, environmental disclosure in the Jordanian industrial companies.

\section{Problem of the Study}

Studies in in accounting and administrative thinking have recently stressed the importance of adding new responsibilities to economic units in addition to their main responsibilities towards their contributors. Such a new responsibility is called the social responsibility because economic units try to achieve a kind of social development for different parties in the society in addition to the economic objectives of economic units which are achieving the suitable profits to their contributors. Accountants see that accounting should have a social dimension through a positive contribution to the prosperity of society, which can be done by evaluation and disclosure of the performance of organizations, especially the economic ones and accomplishing their responsibilities towards society. Also, the investor needs information to help him take a decision about the investment in stocks, and he can obtain such information from different sources, such as financial reports and statements. Therefore, this study tries to answer the following questions: Is there a relation between the size of environmental accounting disclosure of public contributing companies and the sufficiency of disclosure in the financial statements of these companies?

Is there a relation between the controllers of environmental disclosure, such as the company size, its economic performance, environmental legalizations and the nature of activity, and the investment decision in these companies?

Is there a relation between investors' decisions and the information provided by social disclosure about group performance?

Is there a relation between environment costs and the quality of accounting information?

\section{Hypotheses of the Study}

Hypothesis 1: There is no significant statistical relation between the size of environmental accounting disclosure of public contributing companies and the sufficiency of financial statements of these companies.

Hypothesis 2: There is no significant statistical relation between the controllers of environmental disclosure, such as the company size, its economic performance, environmental legalizations and the nature of activity, and the investment decision in these companies.

Hypothesis 3: There is no significant statistical relation between investors' decisions and the information provided by social disclosure about group performance.

Hypothesis 4: There is no significant statistical relation between environment costs and the quality of accounting information.

\section{Model of the Study}

Independent variables

Dependent variable

\section{Previous Studies}

\subsection{Arabic Studies}

Al-Shahada (2010): Accounting Measurement to the Costs of Environmental Performance of the Syrian Public 
Company for Fertilizers and its Impact on its Competitive Ability in Quality.

This study aimed to show the ability of the accounting system applied in the Syrian public company for fertilizers to provide useful information that help to (a) measure the costs of environmental performance of the company, (b) analyze costs of environmental performance and its control, and (c) see the impact of that on its competitive ability and the market share of the company. The most important conclusion of the study was the contradiction between the requirements of environment protection and the efficient economic exploitation of the resources of the company, because the company was committed to spend big amounts of money and tolerate considerable efforts to reduce the negative effects of the company activities. This in turn led to a direct impact on the efficiency of the economic performance of the company and increase in the costs of production, which affected the company's ability to compete in prices and quality.

Mahmoud and Rizq (2010): An Introduction to the Administration of Strategic Cost to Support the Competitive Ability for Saudi Contributing Companies according to the Changes in the World New System. Export is the main driver behind the different activities in the different economic sectors of any country. As the economy of the majority of developing countries depends on the exportation of one product, the economy of such countries is quickly affected by any world changes in the price of that product. Therefore, these countries try to diversify their exported products to maintain a reasonable level of economic security in a changeable world. If an organized treaty is applied in the World Trade Organization, the world will become one market with competition as the most important of its characteristics, and every country will try to support its exports to obtain more share in that market in the view of the changes imposed by the economic environment of the new world system. As prices are identified by the market, not the producer, the producer is left with no option but to reduce the production cost as a competitive characteristic that support its exports.

Almarzouqi (2004): Analysis of Environmental Costs and its Importance in the Control of Administrative Decisions: a Field Study of Industrial Companies in Jeddah City.

Sustainable development has attracted the attention of many countries as a basis to preserve the environment for current generations and coming ones. Therefore, interest in environmental issues is no longer restricted to developed countries, but developing ones as well. As the industrial process has a direct effect on environmental pollution and scarcity of natural resources, industrial countries have become under the focus of many local and international organizations. As such, the researcher conducted a field study to investigate environmental costs of industrial companies in the city of Jeddah to spot light on the level of interest of these companies in environmental issues and the nature of environmental costs afforded by these companies. The test tool in the study was a survey questionnaire which was distributed to industrial bodies in the city of Jeddah. The researcher found many important results, for example, the most important environmental issues that should be considered by industrial companies are fumes, gases and contaminated water. Interestingly, the majority of industrial bodies were found to be aware of these issues, and they increased their interests in environmental issues through advertising campaigns and training sessions, especially to their staff to make them aware of environmental issues.

Abu Khashabih (2002): The Importance and Role of Environmental Costs in the Field of Decision Taking and Evaluation of Performance: A Suggestion for Saudi Organizations. Abu Khashabih sees that there has recently been a growing interest in environmental costs and how it can be measured, shown in financial statements and integrated into the process of decision making and performance evaluation. He also says that if industrial organizations do not commit to the set levels of pollution, dangerous effects are expected to affect individuals and polluted natural resources. If the industrial organization respects the levels, additional environmental costs will be required, but the returns of such commitment will be useful to society. Abu Khashabih also referred to the reasons behind interest in environmental costs, and these reasons are huge, growing and scrambled. He said that these reasons are not considered in the study of any new project. Abu Khashabih (2002) divided environmental costs into four kinds: Costs of protection activities which aim to reduce and remove causes of pollution.

Costs of evaluation activities which aim to measure, and follow up potential sources of environmental pollution.

Costs of observation activities which aim to control and observe the used materials that might affect the environment.

Costs of failure activities which result from misuse of natural resources, leading to negative effects on the environment.

Saleh Ibrahim Alshaabani (2007): The Need to Implement Information of Environmental Costs in the Making 
of Investment Decisions, Philadelphia Conference, Jordan.

At the beginning of the 19th century, Malthus predicted that there will be famine and deaths in the future because the explosion of population will be higher than the rate of economic growth. Malthus's ideas were reconsidered in the eighties in the last century because researchers stressed the case that society started to destroy itself because of the unstudied decisions, decision maker's behaviors, and some activities were not environmentally considered.

We should take into consideration that fact that the environment has a limited ability to endure human activities. Although this ability is distinguished, exceeding it leads to environmental disorder which will affect the human being himself. Because of the complicated organic long-term relation of polluters, on the one hand, and the intersected financial provision which is represented in the form of capital flow between countries, on the other hand, the issue of environmental costs started to have international dimension and interest. Hence, the issues of depleting resources, environmental pollution and its effect on investment decisions started to affect the views of new economists and businessmen when they make a decision.

\subsection{English Studies}

Kitzman (2001): Environmental Cost Accounting for Improved Environmental Decision Making.

Kitzman discussed in this study the results of The ALOCA Study, which aimed to determine environmental costs, highlight the achieved advantages of mixing environmental issues with production, and show how to reach the best environmental performance. The study distinguished between two types of environmental costs: explicit environmental costs and implicit environmental costs. Also, there was a distinction between the other two types of environmental costs: private costs and public costs.

Kitzman mentioned four examples to clarify how to classify public, private, implicit and explicit costs. Only two examples will be mentioned here: the first example is about explicit costs, which are special to the department. If environmental expenses were ascribed to a specific department, and the statistics of calculations were explicitly mentioned in the calculations of the department, costs are then considered explicit and special to the department. The second example is about implicit costs, which are special to the department. If there was a need for a part of whole, this part is then ascribed to the account of the department. If the use of this part was for environmental issues, its costs are then not clearly classified as environmental costs. Therefore, the cost of this part is considered implicit, but it is ascribed to the department which caused it.

\section{Zachry et al (1998): A Critical Analysis of Environmental Costing.}

This study mentioned that organizations have recently witnessed a constant growth in environmental costs. The study also mentioned that the main interest in the 1970's in work organizations was focused on the total costs they will afford, and whether these costs will increase the competitive ability to the American projects. The study also showed that the transfer of American factories from the city to the countryside was to avoid work laws and regulations, and not because of the laws of Environmental Protection Agency (EPA). Zachry et al. mentioned that there are two types of costs: environmental costs related to the site and environmental costs related to production.

The study concluded that the environmental costs of work organizations became an influential factor in its processes. That is, an increase in environmental costs will provide new information to the managers of factories, and this information will trigger the administration to divide production into industrial cells. Such a way allows a precise determination of all work costs, irrespective of whether these costs were indirect industrial or environmental costs, which helps the organization for a better pricing of its products.

Boer and Hoyt (1998): Environmental Cost Management.

This study stresses the focus on environmental costs which are growing in importance day by day and spread in different organizations, managers do not pay enough attention to them, though. For example, the Environmental Protection Agency (EPA) estimated the spending of American companies by more than $\$ 100$ billion in 1990 and $£ 200$ billion in 1995. In 1983, companies specialized in waste disposable asked for a $\$ 3$ fee for every ton of commercial waste, and in 1993 consumers paid $\$ 130$ per ton for the same service. To clarify the nature and classifications of environmental costs that face managers, Boer and Hoyt studied Myers Industrial Co. as an example, so the nature of environmental costs in that company was detailed to show what managers can do with regards to such costs.

Difference between this Study and Previous Studies

This study is distinguished from previous studies by its attempt to investigate the impact of accounting for 
environmental costs to improve the quality of accounting information in the Jordanian industrial companies, while the majority of previous studies did not address the topic in the Jordanian context.

\section{Characteristics of Study Sample}

Age:

\begin{tabular}{lll}
\hline Age & Repetition & Percentage (\%) \\
\hline Less than 18 yrs. & 27 & 54.0 \\
$19-22$ & 13 & 26.0 \\
$23-26$ & 10 & 20.0 \\
Total & 50 & 100.0 \\
\hline
\end{tabular}

The relative distribution for members of the study sample based on the age variable (factor)

As per the table, it is clear that the percentile of the study sample who's age are under 18 years old was $54 \%$, members of the study sample percentile in the age range 19-22 was $26 \%$, and members of the study sample percentile in the age range $23-26$ was $20 \%$.

\section{Monthly Income:}

The relative distribution for members of the members of the study sample based on the monthly income variable (factor)

\begin{tabular}{lll}
\hline Monthly Income & Repetition & Percentage \\
\hline Less than 200 Dinars & 23 & 46.0 \\
200-300 Dinars & 10 & 20.0 \\
301-400 Dinars & 17 & 34.0 \\
Total & 50 & 100.0 \\
\hline
\end{tabular}

As per the table, it is clear that the percentile of the members of the study sample whose monthly income were less than 200 Dinars was $46 \%$, the percentile of the members of the study sample whose monthly income were between 200 Dinars - 300 Dinars was $20 \%$, and the percentile of the members of the study sample whose monthly income were between 301-400 Dinars was 34\%.

\section{Educational Level:}

The relative distribution for members of the study sample based on the educational level variable (factor)

\begin{tabular}{lll}
\hline educational level & Repetition & Percentage (\%) \\
\hline Bachelor & 31 & 62.0 \\
Master & 19 & 38.0 \\
Total & 50 & 100.0 \\
\hline
\end{tabular}

As per the table, it is clear that the percentile of the members of the study sample who hold a bachelor degree only was $62 \%$, and the percentile of the members of the study sample who hold a master degree was $38 \%$.

\subsection{Hypothesis Testing}

\section{First Hypothesis}

There is no statistically significant relationship between the size of the environmental-related accounting disclosure of the publicly shared companies and the adequacy of the financial statements of these companies.

To examine this hypothesis, a "T" test was conducted for an individual sample, and the following table shows the "T" test results:

\begin{tabular}{llll}
\hline Average & Standard Deviation & "T" & Significance \\
\hline
\end{tabular}


As per the table, it is clear that the calculated " $T$ " value hasn't reached a considerable statistical significance; this indicates that there exists a statistically significant relationship between the size of the environmental-related accounting disclosure of publicly shared companies and the adequacy of the financial statements of these companies.

\section{Second Hypothesis}

There is no statistically significant relationship between the determinants of the environmental-related accounting disclosure of the publicly shared companies (represented by its size, economical performance, environmental legislations, and the nature of its' business) and the investment decision taken in these companies.

To examine this hypothesis, a "T" test was conducted for an individual sample, and the following table shows the "T" test results:

\begin{tabular}{llll}
\hline Average & Standard Deviation & "T" & Significance \\
\hline 21.8800 & 4.415 & 7.01 & 0.000 \\
\hline
\end{tabular}

As per the table, it is clear that the calculated "T" value hasn't any statistical significance; this indicates that there exists a statistically significant relationship between the determinants of the environmental-related accounting disclosure of the publicly shared companies (represented by its size, economical performance, environmental legislations, and the nature of its' business) and the investment decision taken in these companies.

\section{Third Hypothesis}

There is no statistically significant relationship between the decisions undertaken by the investors and the information provided by the disclosure of the collective performance.

\begin{tabular}{llll}
\hline Average & Standard Deviation & "T" & Significance \\
\hline 20.2400 & 1.779 & 20.82 & 0.000 \\
\hline
\end{tabular}

As per the table, it is clear that the calculated "T" value hasn't any significant statistical significance; this indicates that there exists a statistically significant relationship between There is no statistically significant relationship between the decisions undertaken by the investors and the information provided by the disclosure of the collective performance.

\section{Fourth Hypothesis}

There is no statistically significant relationship between the environmental-relates costs and the quality of accounting information.

\begin{tabular}{llll}
\hline Average & Standard Deviation & "T" & Significance \\
\hline 22.250 & 1.002 & 19.28 & 0.000 \\
\hline
\end{tabular}

As per the table, it is clear that the calculated "T" value hasn't any significant statistical significance; this indicates that there exists a statistically significant relationship between environmental-related costs and the quality of accounting information.

\section{Summary, Results, and Recommendations}

\subsection{Summary}

This study was aimed to clarify the effect of environmental-related disclosure on investment decisions, undertake by the publicly owned companies, companies whose shares are enlisted in Amman Stock exchange, these policies effects on investment decisions undertaken as well in investing in such companies, and to clarify the adequacy and importance of information to decision making.

In order to test the study hypothesis, a questionnaire was designed and distributed among a randomly picked sample of all companies enlisted in the Amman Financial Market.

Questionnaires distributed by the researcher were then collected, and the information within these questionnaires were input using the statistical software SPSS.

The study's statistical results have shown that there exists a significant effect for environmental-related 
disclosure on the decisions of the investors. Therefore, the researcher highly recommends conducting such informative disclosure by publicly owned companies in Jordan as to encourage businessmen to invest in it.

\subsection{Results}

The study has shown that there exists a significant statistical relationship between the size of environmentally-related accounting disclosure of information for publicly owned companies and the adequacy of financial listing of such companies.

The study has shown that there exists a significant statistical relationship between the determinants of environmentally-related accounting disclosure of information (expresses by the company size, economical performance, its environmental legislations, and the nature of business) for publicly owned companies and the investing decisions undertaken in such companies.

The study has shown that there exists a significant statistical relationship between Investors decisions and the information provided by the collective performance disclosure.

The study has shown that there exists a significant statistical relationship between environmentally-related costs and the quality of accounting information.

\subsection{Recommendations}

As per the study results, we recommend the following:

The necessity of accountants' obligation towards environmentally-related auditing of information provided with the financial reports.

The necessity of emphasizinginformation importance as provided by the environmentally-related collective performance.

The necessity that companies committed towards international standards related to environmental auditing.

The necessity of the fulfillness and adequacy of the auditing procedures on all information needed by the investors.

\section{References}

Beets, S. D., \& Souther, C. (n.d.). Corporate Environmental Reports: The need for standards and air environmental assurances. Accounting Horizons, 13(2).

Blocher, E., Chem, H. (2002). Thomas Cost Management A: Strategic Emphasis (2nd ed.). Mcgvaw Hill Co.

Boer, G., M., \& Hoyt, L. (1998). Environmental Cost Management, Management Accounting, 28-38.

Burritt, R. L., \& Saka, C. (n.d.). Environmental Management Accounting Applications and Eco-Efficiency: Case Studies from Japan. Journal of Cleaner Production, 14(14).

Chiraka, R. (2008). Strategic Cost Management Accounting: Context and Philosophy. SA.

Jasch. C. (n.d.). Environmental and Material Flow Cost Accounting: Principles and Procedures.Eco-Efficiency in Industry and Science, 25. Springer. Heidelberg, NewYork.

Kitzman, K. (2001). Environmental Cost Accounting for Improved Environmental Decision Making, Pollution Engineering, 20-23.

Lucas, M (1997). Standard costing and its role in today's manufacturing environment. Management accounting.

Zachry, B., Gaharan, C., \& Chaisson, M. (1998). A Critical Analysis of Environmental Costing. American Business Review.

\section{Copyrights}

Copyright for this article is retained by the author(s), with first publication rights granted to the journal.

This is an open-access article distributed under the terms and conditions of the Creative Commons Attribution license (http://creativecommons.org/licenses/by/4.0/). 